\title{
The Effect of Weight Training Method and Aerobic Endurance on the Improvement of Anaerobic Endurance
}

\author{
Rian Dio Juliandri \\ Master Program in Sport Sciences \\ Yogyakarta State University \\ Sleman, Indonesia \\ rdjuliandri@gmail.com
}

\author{
Yustinus Sukarmin \\ Master Program in Sport Sciences \\ Yogyakarta State University \\ Sleman, Indonesia \\ Yustinus_sukarmin@uny.ac.id
}

\begin{abstract}
- the aim of this research was to understand the effects of weight training method with the use of single set and multiple sets system and aerobic endurance in improving anaerobic endurance. This research made use of experimental method of $2 \times 2$ factorial design. The population in this study were 33 football players of PS FKIP UNIB. Purposive sampling technique was employed in this study and 18 people participated. The instruments used in this study were aerobic endurance tests through the use of Cooper test as well as anaerobic endurance through the use of running-based anaerobic sprint test. The result revealed that weight training with multiple sets system was more significant in increasing anaerobic endurance rather than exercises with single set system.
\end{abstract}

Keywords-weight training, single set, multiple sets, aerobic, anaerobic

\section{INTRODUCTION}

Football is the most popular sport in the world, Indonesia inclusive. In fact, it has become the most popular sport. Almost all men from children, teens, youth to the elderly play football even though their goals are different, some people play just for recreation, fitness, hobby or a pleasure, while others play to achieve some certain goals [1]. In football, players must understand and know the basic techniques correctly, besides that, the physical factors and basic techniques of playing football are important factors in achieving certain goals. [2] The performance level of football players depends on many simultaneous factors, including athletic, technical, tactical, mental, and physiological abilities. Therefore, football is one of many sports that guide players to have good physical ability. Physical condition is crucial in supporting the athlete's job during a match so they can perform optimally.

One of the most important physical elements in football is endurance. The long duration and the high intensity of the game, require that players should have maximum durability [3]. Endurance is a very important physical factor, which determines how far an athlete can go in the sport. This is because effective endurance ability of an athlete helps in the application of techniques and tactics, optimally, on the field of play. Therefore, good endurance enables easy achievement. Endurance is divided into aerobic endurance and anaerobic endurance [4]. Football is a game that really needs aerobic and anaerobic capacity since they are both equally important. This is because of different activities in the game such as short sprint, relaxing, recovery and movements. Players must cover large areas of the field during attack and defense. Therefore, football seriously requires aerobic and anaerobic fitness.
Aerobic fitness is needed so that players do not quickly experience fatigue since the duration used in playing football is so long [5]. Aerobic capacity is a limiting factor in maximal secondary ability because it only determines whether fatigue will come fast or slow. It means that fatigue is not determined by aerobic capacity. If the aerobic capacity is large, fatigue will come slowly, whereas if aerobic capacity is small, fatigue will come quickly.

In football game, a player must surely master different techniques such as shooting, heading, dribbling and sprinting to create goals and control the game. In mastering these basic techniques, players need good anaerobic endurance one of which is muscle strength and endurance [6]. Without a good anaerobic ability, an athlete will not be able to work with high intensity in short duration or work explosively.

The fact is that most coaches only focus on aerobic endurance training programs and tactics, whereas, muscular endurance is also very important. This is because of the fact that it is essential in carrying out various functions on the field of play. In order to train in anaerobic ability, coaches must include an anaerobic exercise program, which is weight training to improve the muscle endurance of their players [7]. Sports that require huge power in a short time such as heavy lifting, push up, sprints or long jumps are kinds of sport with more dominant anaerobic activity components.

Weight training is divided into two types which are using own weight and using tools. Weight training by using own weight or bodyweight is more efficient, because the exercises can be done anywhere, it is economical and saves time [8]. Most weight training only isolates certain muscles, unlike bodyweight exercises that involve multiple muscles in a single motion. Bodyweight exercises are also safer from severe injuries like joint injuries that come frequently from weight lifting. There are two weight training systems that can be used which are single set and multiple sets. Single set is a weight training system that uses only one set with maximum repetition or up to failure [9]. The benefits of a single set exercise include time efficiency which comes as a result of the generation of the same power at a shorter period of time. Multiple sets, on the other hand, is a weight training system that makes use of three sets and which has the ability of varying the number of repetition in each [10]. Multiple sets system may involve some sets with the same resistances or multiple sets with various resistances (i.e. weight to light, light to heavy) with varying number or equal number of repetitions per set. This training 
system became popular in the 1940s and has become the forerunner of multiple sets systems today.

Both weight training systems are suitable for weight training using own weight because coaches can increase the workload by varying the movement, number of sets, repetitions, and rest periods.

\section{METHOD}

\section{A. Research Design}

This research was an experimental research aimed at knowing the effect of independent and dependent variables with the use of $2 \times 2$ factorial design [11]. Factorial design is a modification of true experimental design with regards to the possibility of moderating variables that affect the treatment (independent variable) on outcomes (dependent variables). The treatment in this research was the weight training with single set and multiple set method. The level of each treatment in this study was founded on the high and low of $\mathrm{VO}_{2} \mathrm{Max}$ level that the athletes have. The result of such treatments was used to assess the anaerobic endurance.

Furthermore, the research designs undertaken by the researcher are described in more detail in Table 1 as follows:

TABLE $1.2 \times 2$ FACTORIAL DESIGN TABLE

\begin{tabular}{|c|c|c|}
\hline $\begin{array}{c}\text { Exercise Methods (A) } \\
\text { Aerobic Endurance (B) }\end{array}$ & $\begin{array}{c}\text { High Aerobic } \\
\text { Endurance (B1) }\end{array}$ & $\begin{array}{c}\text { Low Aerobic } \\
\text { Endurance (B2) }\end{array}$ \\
\hline Single set (A1) & A1B1 & A1B2 \\
\hline Multiple sets (A2) & A2B1 & A2B2 \\
\hline
\end{tabular}

Description:

Al : Group with single set exercise.

A2 : Group with multiple set exercise.

B1 : Group with high aerobic endurance.

B2 : Group with low aerobic endurance.

A1B1 : Group with single set exercise that have high aerobic endurance.

A1B2 : Group with single set exercise that have low aerobic endurance.

A2B1 : Group with multiple sets exercise that have high aerobic endurance.

A2B2 : Group with multiple sets exercise that have low aerobic endurance.

\section{B. Time and Place of Study}

The research was carried out on the football field of PS FKIP UNIB in Bengkulu City. There was adjustment of time to their training schedule for 5 weeks at a frequency of 3 times a week fixed for Wednesdays, Fridays and Sundays.

\section{Population and Sample}

The population of this study was the 33 football players of PS FKIP UNIB Bengkulu City. By using purposive sampling technique, 18 players participated as the sample of this study.

\section{Technique and Instrument of Data Collection}

Instrument of the study was aerobic endurance test with 2.4 $\mathrm{km}$ Cooper test and anaerobic endurance test with runningbased anaerobic sprint test.

\section{RESULT}

The results showed a decrease in fatigue index in each of the dependent variable, which means that there is an increment in anaerobic endurance. Group with single set exercise that had high aerobic endurance reduced the fatigue index as much as 9.86. While single set exercise group that has low aerobic endurance also decreased the fatigue index by 2.88 . The improvement of anaerobic endurance also occurred in group with multiple sets that had high aerobic endurance, it decreased the fatigue index by 17.18 . While group with multiple sets exercise that had low aerobic decreased the fatigue index by 11.63. Details of these can be seen in Table 2 .

TABLE 2. DATA DESCRIPTION

\begin{tabular}{|c|c|c|c|c|}
\hline No. & $\begin{array}{l}\text { Exercise } \\
\text { Methods }\end{array}$ & $\begin{array}{c}\text { Aerobic } \\
\text { Endurance }\end{array}$ & Data & $\begin{array}{l}\text { Anaerobic } \\
\text { Endurance }\end{array}$ \\
\hline \multirow{6}{*}{1.} & \multirow{6}{*}{ Single set } & \multirow{3}{*}{ High } & Pretest & 37,27 \\
\hline & & & Posttest & 27,41 \\
\hline & & & Difference & 9,86 \\
\hline & & \multirow{3}{*}{ Low } & Prertest & 41,62 \\
\hline & & & Posttest & 38,74 \\
\hline & & & Difference & 2,88 \\
\hline \multirow{6}{*}{2.} & \multirow{6}{*}{ Multiple Sets } & \multirow{3}{*}{ High } & Pretest & 31,65 \\
\hline & & & Posttest & 14,47 \\
\hline & & & Difference & 17,18 \\
\hline & & \multirow{3}{*}{ Low } & Pretest & 58,7 \\
\hline & & & Posttest & 47,07 \\
\hline & & & Difference & 11,63 \\
\hline
\end{tabular}

The decrease in fatigue index observed in Table 2 is not enough to conclude that there was significant improvement yet and that there was no significant difference in between single set exercise and multiple sets exercise. To be able to have a valid answer to the hypothesis, there was need for further test by using hypothesis testing. Hypothesis test was carried out by using two path ANOVA with the help of SPSS 16.0. Details of these can be seen in Table 3 and Table 4.

TABLE 3. TESTS BETWEEN-SUBJECTS EFFECTS

\begin{tabular}{|l|c|c|c|c|c|}
\hline \multicolumn{1}{|c|}{ Source } & $\begin{array}{c}\text { Type III Sum } \\
\text { of Squares }\end{array}$ & $\boldsymbol{d f}$ & Mean Square & $\boldsymbol{F}$ & Sig. \\
\hline Corrected & $24.936^{\mathrm{a}}$ & 3 & 8.312 & 71.191 & .000 \\
Model & 98.921 & 1 & 98.921 & 847.248 & .000 \\
Intercept & 16.099 & 1 & 16.099 & 137.890 & .000 \\
Exercise & 10.667 & 1 & 10.667 & 91.366 & .000 \\
Aerobic & .783 & 1 & .783 & 6.707 & .021 \\
Exercise $*$ & 1.635 & 14 & .117 & & \\
Aerobic & 124.757 & 18 & & & \\
Error & 26.570 & 17 & & & \\
Total & & & & & \\
Corrected & Total & & & & \\
\hline
\end{tabular}


TABLE 4. ESTIMATED MARGINAL MEANS FOR EXERCISE METHODS ON ANAEROBIC ENDURANCE IMPROVEMENT

\begin{tabular}{|c|c|c|c|c|}
\hline \multirow{2}{*}{$\begin{array}{c}\text { Exercise } \\
\text { Methods }\end{array}$} & \multirow{2}{*}{ Mean } & \multirow{2}{*}{ Std. Error } & \multicolumn{2}{|c|}{ 95\% Confidence Interval } \\
\cline { 4 - 5 } & & & Lower Bound & Upper Bound \\
\hline Single set & 1.407 & .115 & 1.161 & 1.653 \\
Multiple Sets & 3.311 & .115 & 3.065 & 3.556 \\
\hline
\end{tabular}

The result of the analysis revealed that there was significant difference between single set and multiple sets exercise methods on players' anaerobic endurance improvement of PS FKIP Bengkulu, this is evident from the result of the ANOVA test with $F_{\text {calculate }}=137.89$ with the level of significance $0.00<0.05$. Therefore, Multiple sets exercise method was found to be better than single set in improving anaerobic endurance. Multiple sets exercise method claimed the average score 3.311 for anaerobic endurace, while single set exercise method claimed the average score 1.407. The average score of exercise methods on players' anaerobic endurance of PS FKIP Bengkulu who did multiple sets exercise method was bigger than single set exercise method and it had significant difference. Therefore, it can be deduced that multiple sets exercise method improves anaerobic endurance better than single set exercise method.

\section{CONCLUSION AND SUGGESTION}

\section{A. Conclusion}

Based on the results of the analysis and discussion that follows, it can be concluded that there was a significant difference of influence between single set and multiple sets exercise methods in increasing or improving anaerobic endurance.

\section{B. Suggestion}

There are two suggestions and they are as follows:

1. Coaches can use weight training methods with multiple sets system to improve players' anaerobic ability.

2. Further researchers are advised to expand the purpose of using single set and multiple sets exercise methods, it is expected not only focus for anaerobic endurance improvement.

\section{REFERENCES}

[1] A. S. Mulyana, I. Imanudin, and S. T. Paramitha, "Analisis kondisi fisik dan teknik dasar sepak bola ekstrakurikuler sepak bola SMAN 2 Ciamis," Unpublished Dissertation, Universitas Pendidikan Indonesia, Bandung, 2013

[2] C. Manouvrier, J. Cassirame, and S. Ahmaidi, "Proposal for a specific aerobic test for football players: the footeval," Journal Sport Science and Medicine, 15, pp. 670-677, 2016.

[3] M. F. S. Budi, "Circuit training dengan rasio 1:1 dan rasio 1:2 terhadap peningkatan $\mathrm{vo}_{2}$ max," Journal of Sport Sciences and Fitness, vol. 4, pp. 53-58, 2015.

[4] P. Nayak, S. Mondal, and A. Gayen, "Aerobic fitness of Indian soccer players: field methods analysis," International Journal Of Engineering And Science, vol. 4, pp. 18-21, 2015.
[5] S. Giriwijoyo, and D. Z. Sidik., "Ilmu faal olahraga.," Bandung: Remaja Rosdakarya, 2012.

[6] Sukadiyanto, "Pengantar teori dan metodologi melatih fisik," Yogyakarta: FIK Universitas Negeri Yogyakarta, 2010.

[7] A. Irawan, "Metabolisme energi tubuh \& olahraga," Polton Sport Science \& Performance Lab, vol. 1, pp. 1-9, 2007.

[8] M. Lauren, and J. Clark, "You are your own gym," New Orleans: Light of New Orleans Publishing, 2010.

[9] Carpinelli, "Berger in retrospect: effect of varied weight training programmes on strength," Journal Sports Med, vol. 36, pp. 319-324, 2002.

[10] S. J. Fleck, and W. J. Kraemer, "Designing resistance training programs, ” United States: Human Kinetics, 2014.

[11] Sugiyono, "Metode penelitian kombinasi," Bandung: Alfabeta, 2015. 